
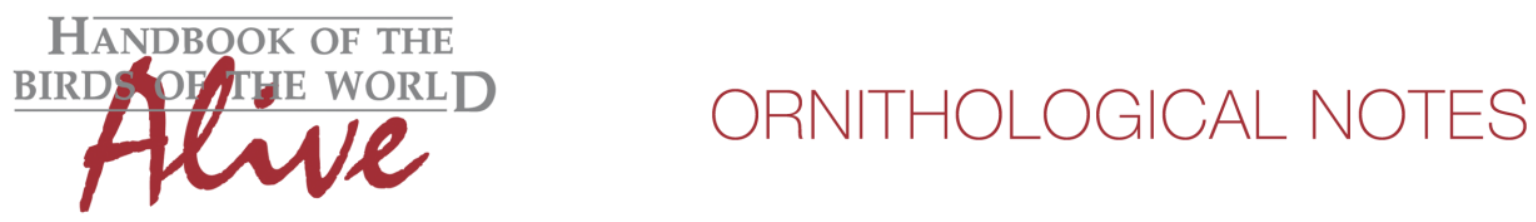

\title{
Notes on the vocalizations of Cozumel Wren (Troglodytes beani)
}

Peter Boesman

In the following we briefly analyze and compare voice of Cozumel Wren (Troglodytes beani) with other members of the House Wren complex. We also try to quantify the extent of any vocal differences using the criteria proposed by Tobias et al. (2010), as a support for taxonomic review. We have made use of sound recordings available on-line from Xeno Canto (XC) and Macaulay Library (ML).

Voice of members of the House Wren complex is very variable among races, and the groups 'Northern House Wren', 'Brown-throated Wren' and 'Southern House Wren' don't seem to have obvious vocal differences. On the other hand, 'Cozumel Wren' beani differs strikingly in having a much simpler song: several grating or scratchy notes followed typically by one or two series of pure whistles, which can reach low pitches. Some examples:

beani

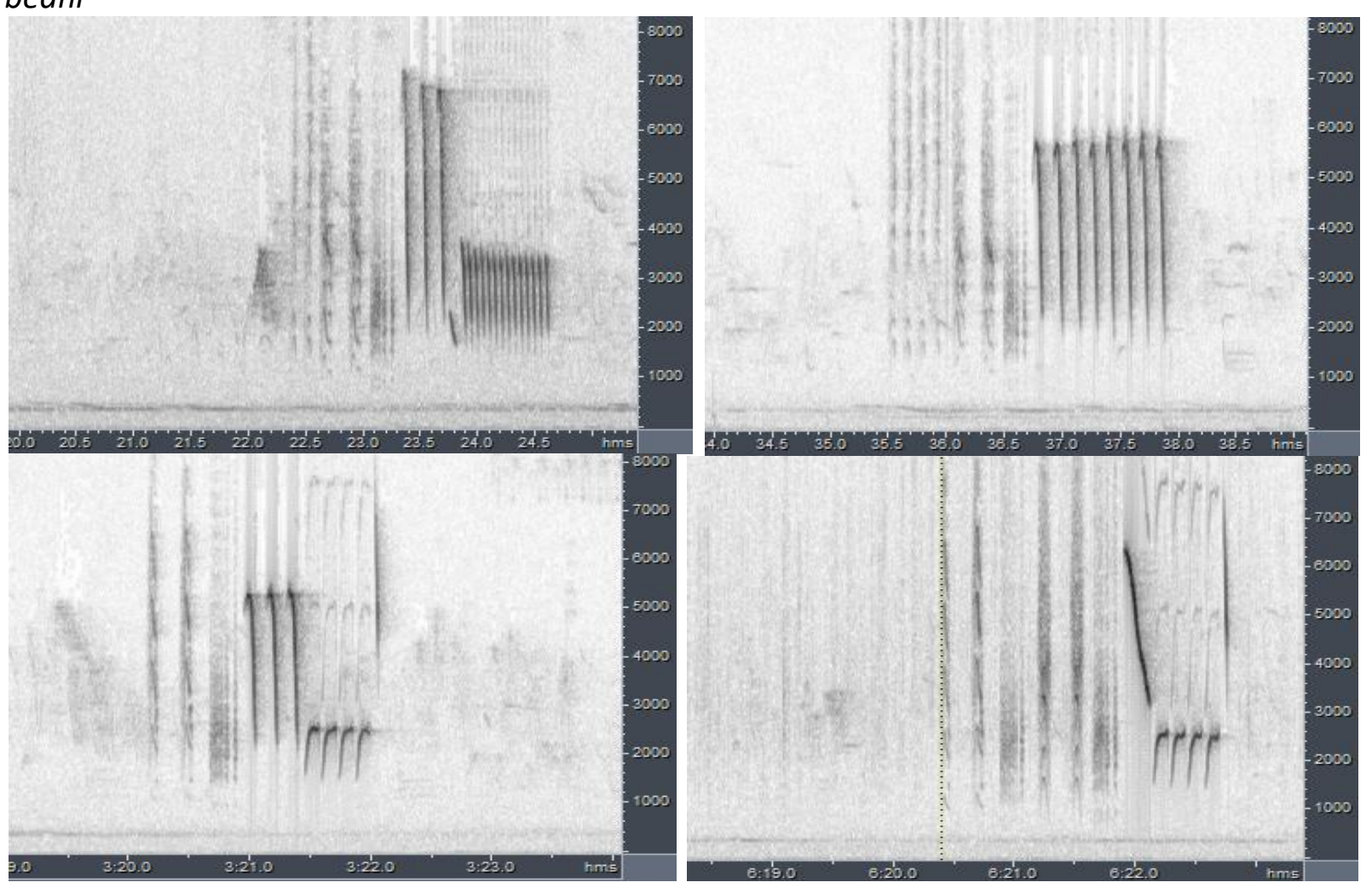


HANDBOOK OF THE

BIRDSPF TUE WORLD

ORNITHOLOGICAL NOTES
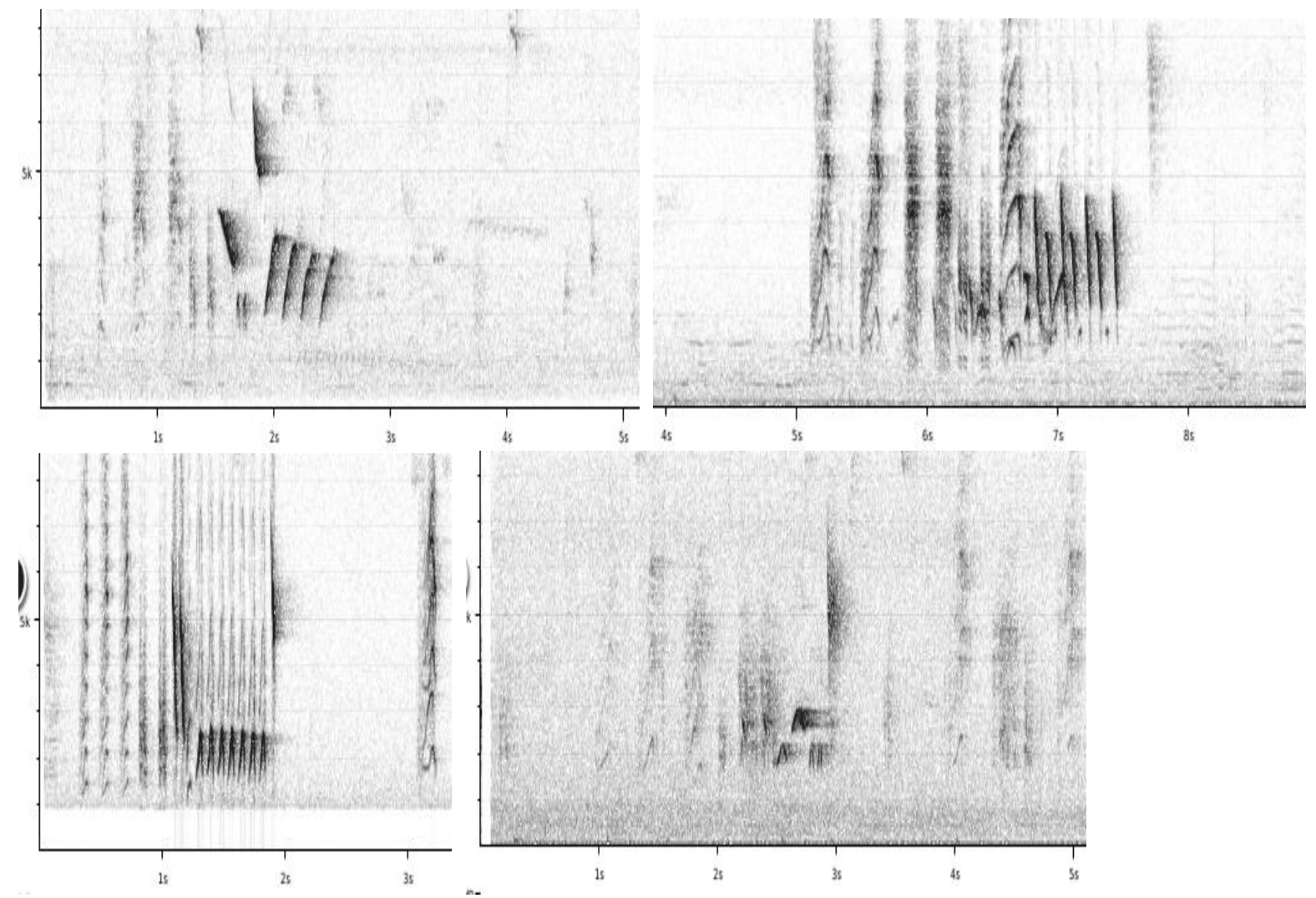

To be compared with some typical examples of song of the 'House Wren complex':

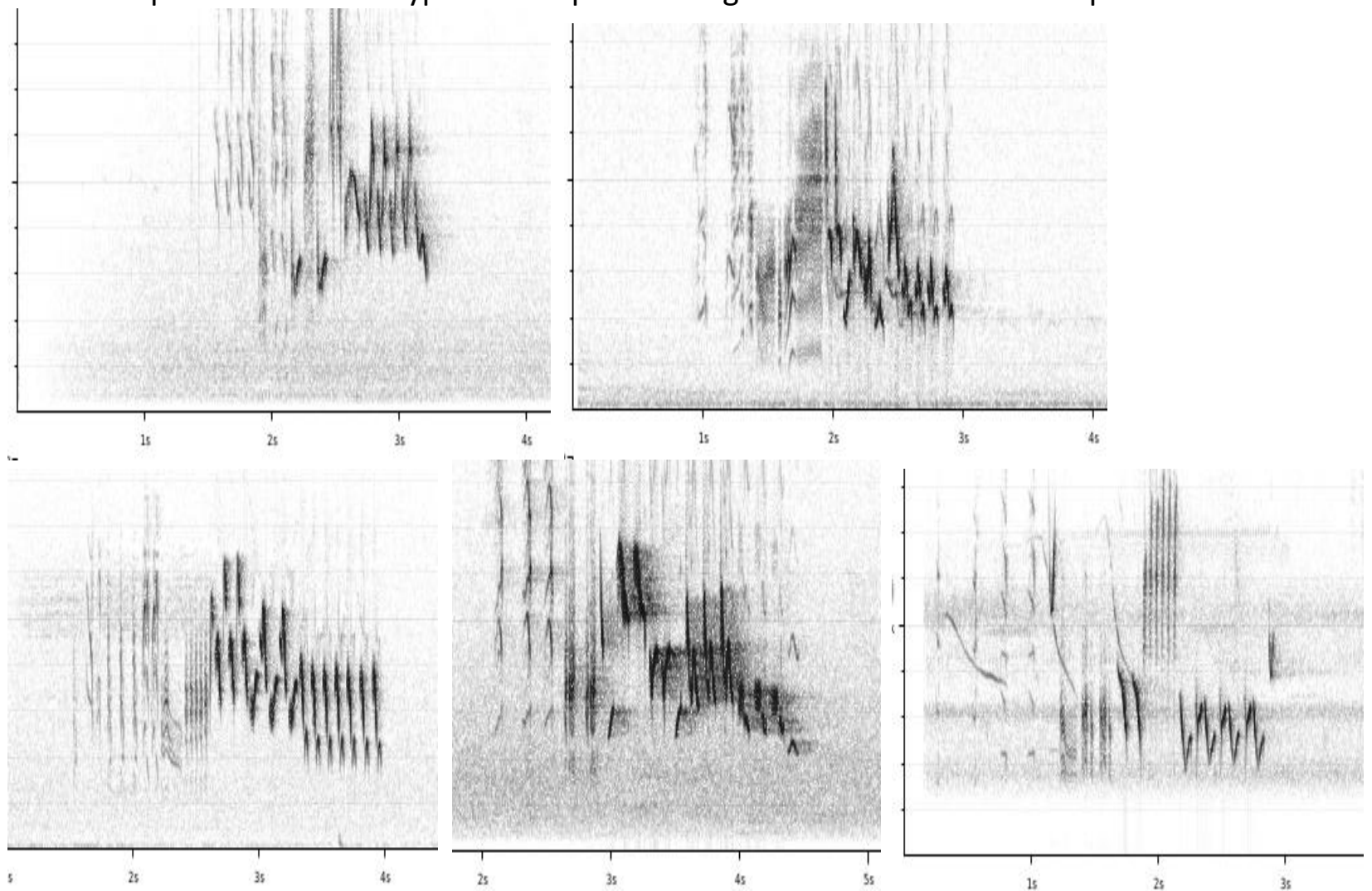



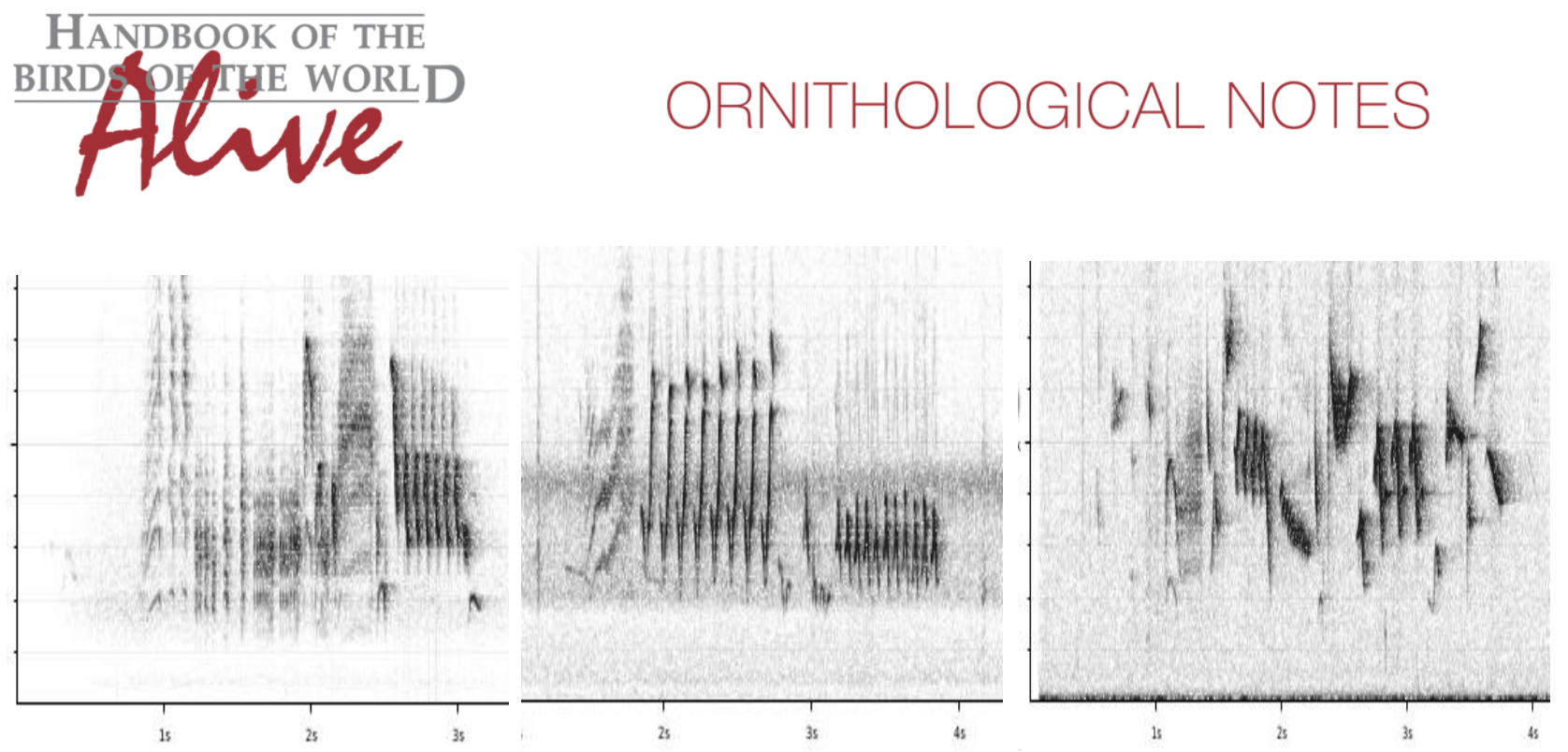

It would seem that in beani, after the scratchy introductory notes, the whistled phrase is limited to only two parts consisting of one or more identical whistles, which are very simple in shape. All other races in contrast typically have the scratchy introductory notes (if present) typically followed by several parts which may consist of alternating whistles, again a few scratchy notes, different fairly complex notes etc.

beani can thus be identified based on the few different whistled notes (typically 1 to 3 different note series vs. typically 4-5, score 2-3), with notes which are simpler and purer, reflected in the note shape (score 1 ) and usually the lower minimum frequency.

When applying Tobias criteria, this would lead to a total vocal score of about 3-4.

This note was finalized on 27th April 2016, using sound recordings available on-line at that moment. We would like to thank in particular the many sound recordists who placed their recordings for this species complex on XC and ML.

\section{References}

Tobias, J.A., Seddon, N., Spottiswoode, C.N., Pilgrim, J.D., Fishpool, L.D.C. \& Collar, N.J. (2010). Quantitative criteria for species delimitation. Ibis 152(4): 724-746.

\section{Recommended citation}

Boesman, P. (2016). Notes on the vocalizations of Cozumel Wren (Troglodytes beani). HBW Alive Ornithological Note 284. In: Handbook of the Birds of the World Alive. Lynx Edicions, Barcelona. (retrieved from http://www.hbw.com/node/1251726 on 12 October 2016). 